\title{
Inflammation is associated with desynchronosis in the immune system (experimental study)
}

\author{
Abdalova A.M. \\ Research Institute of Clinical and \\ Experimental Lymphology - Branch of \\ the Institute of Cytology and Genetics \\ SB RAS \\ Novosibirsk, Russia \\ arzuabd@mail.ru
}

Klimontov V.V.

Research Institute of Clinical and

Experimental Lymphology - Branch of

the Institute of Cytology and Genetics

SB RAS

Novosibirsk, Russia

klimontov@mail.ru

\author{
Shurlygina A.V. \\ Research Institute of Clinical and \\ Experimental Lymphology - Branch of \\ the Institute of Cytology and Genetics \\ SB RAS \\ Novosibirsk, Russia \\ anna_v_s@mail.ru
}

Letyagin A.Yu.

Research Institute of Clinical and

Experimental Lymphology - Branch of

the Institute of Cytology and Genetics

SB RAS

Novosibirsk, Russia

letyagin-andrey@yandex.ru

\author{
Dergacheva T.I. \\ Research Institute of Clinical and \\ Experimental Lymphology - Branch of \\ the Institute of Cytology and Genetics \\ SB RAS \\ Novosibirsk, Russia \\ dr-tanja@yandex.ru
}

\begin{abstract}
The circadian temporary organization of the dynamic processes occurring at the level of the cellular compartment of the immune system ensures their clear time sequence, the optimal ratio of cellular elements in organs and tissues at any given time/ Any pathological process leads to biorhythmological disorders of varying severity, which begin at the very early stages of the disease, when clinical signs are not yet manifested. However, in the literature there is very little information about the daily biorhythms of the immune system in violation of its functions, in particular, in the chronic inflammatory process. We found that with inflammation in the thymus, spleen and lymph nodes, the nature of the diurnal fluctuations in the content of large, medium and small lymphocytes, monocytes / macrophages, CD8 +, CD25 + cells changes. Thus, with the development of inflammation in the uterine mucosa in rats, desynchronosis in the immune system is observed. This allows us to talk about the need to take into account circadian rhythms in the diagnosis and treatment of inflammatory diseases.
\end{abstract}

Keywords - inflammation, circadian rhythm, thymus, spleen, lymphatic nodes, CD4+ and CD8+ lymphocytes

\section{Introduction}

The circadian temporary organization of the dynamic processes occurring at the level of the cellular compartment of the immune system ensures their clear time sequence, the optimal ratio of cellular elements in organs and tissues at any given time [3]. Any pathological process leads to biorhythmological disorders of varying severity, which begin at the very early stages of the disease, when clinical signs are not yet manifested [2]. The study of biorhythms of indicators of the morphofunctional state of immunocompetent cells, their cytokine-producing activity and ability to respond to regulatory factors is of great importance for elucidating the mechanisms of immunopathological processes. However, in the literature there is very little information about the daily biorhythms of the immune system in violation of its functions, in particular, in the chronic inflammatory process.

\section{Methods and Algorithms}

In female Wistar rats, a model of experimental endomyometritis was created [1]. On the 13th day after the induction of inflammation, rats were sacrificed by decapitation under ethinal anesthesia at 10.00 and at 20.00. Thymus, spleen, inguinal, iliac and para-aortic lymph nodes were removed. In lymphoid organs, the percentage of CD8 + and CD25 + lymphocytes were determined by flow cytometry with FITC-labeled monoclonal antibodies (BD Pharmingen) using a FACSCalibur flow cytometer (Becton Dickinson). In smears from a cell suspension of lymphoid organs stained by the Romanovsky-Giems method, the percentage of various cell forms - large, medium, small lymphocytes, and monocytes / macrophages - was determined. Statistical processing was performed using the STATISTICA6 software package.

\section{Results}

In intact female Wistar rats, the percentage of large, small, CD25 + cells and monocytes / macrophages was increased in the thymus at $10.00 \mathrm{~h}$ compared to $20.00 \mathrm{~h}$, the percentage of CD8 + cells were reduced. In the morning, a higher content of large and small lymphocytes and CD25 + splenocytes was noted in the spleen. The percentage of monocytes / macrophages was increased at $20.00 \mathrm{~h}$. Morning-evening differences were revealed in all lymph nodes for the percentage of secondary lymphocytes (Table 1).

With inflammation morning-evening differences were revealed only for the percentage of large and medium thymocytes. In the spleen for large lymphocytes and CD25 + splenocytes an "inversion" of diurnal fluctuations was found, and for the percentage of monocytes / macrophages a decrease in the difference between morning and evening values was found. Significant diurnal fluctuations in the percentage of medium and small lymphocytes disappear in the paraortic lymph nodes, but morning and evening differences for the content of CD $8+$, CD25 + cells and monocytes / macrophages appear. In the inguinal lymph nodes, the morning and evening differences in the content of middle lymphocytes are leveled, but they appear for the percentage of large, small lymphocytes and CD8 + cells. Significant diurnal fluctuations in the percentage of large lymphocytes, CD8 + cells and monocytes / macrophages appear in the iliac lymph nodes. Daily variations in the content of middle lymphocytes are inverted (Table 1). 
TABLE I DAILY VARIATIONS IN THE CELLULAR COMPOSITION OF THE LYMPHOID ORGANS OF FEMALE RATS INTACT AND ON THE 13TH DAY OF THE DEVELOPMENT OF EXPERIMENTAL ENDOMYOMETRITIS $(\mathrm{M} \pm \mathrm{SE})$

\begin{tabular}{|c|c|c|c|c|c|}
\hline Cells (\%) & Int. $10.00 \mathrm{~h}$ & \multicolumn{2}{|c|}{ Int. $20.00 \mathrm{~h}$} & $\begin{array}{l}\text { Inf. } \\
10.00 \\
h\end{array}$ & $\begin{array}{l}\text { Inf. } \\
20.00 \\
\text { h }\end{array}$ \\
\hline \multicolumn{6}{|c|}{ Thymus } \\
\hline Large lymphocytes & $\begin{array}{l}25,32 \pm \\
2,21\end{array}$ & $\begin{array}{l}14,51 \pm \\
1,87^{*}\end{array}$ & $\begin{array}{l}21,2 \pm \\
1,02\end{array}$ & & $\begin{array}{l}13,3 \pm \\
1,93 *\end{array}$ \\
\hline $\begin{array}{l}\text { Middle } \\
\text { lymphocytes }\end{array}$ & $\begin{array}{l}21,81 \pm \\
2,22\end{array}$ & $\begin{array}{l}40,52 \pm \\
3,01\end{array}$ & $\begin{array}{l}17,6 \pm \\
1,43 \\
\end{array}$ & & $\begin{array}{l}34,1 \pm \\
2,59 *\end{array}$ \\
\hline Small lymphocytes & $\begin{array}{l}58,24 \pm \\
1,28 \\
\end{array}$ & $\begin{array}{l}31,25 \pm \\
0,26^{*} \\
\end{array}$ & $\begin{array}{l}54,2 \pm \\
2,02 \\
\end{array}$ & & $\begin{array}{l}41,8 \pm \\
3,81 \\
\end{array}$ \\
\hline CD8+ & $\begin{array}{l}48,12 \pm \\
0,11 \\
\end{array}$ & $\begin{array}{l}69,45 \pm \\
0,08^{*}\end{array}$ & $\begin{array}{l}59,6 \pm \\
0,08 \\
\end{array}$ & & $\begin{array}{l}70,1 \pm \\
0,07\end{array}$ \\
\hline CD25+ & $\begin{array}{l}9,21 \pm 0,0 \\
3\end{array}$ & $\begin{array}{l}4,35 \pm \\
0,01 \\
\end{array}$ & $\begin{array}{l}6,13 \pm \\
0,02 \\
\end{array}$ & & $\begin{array}{l}5,41 \pm \\
0,01\end{array}$ \\
\hline $\begin{array}{l}\text { Monocytes/macrop } \\
\text { hages }\end{array}$ & $\begin{array}{l}4,52 \pm 0,1 \\
2 \\
\end{array}$ & $\begin{array}{l}1,12 \pm \\
0,02 * \\
\end{array}$ & $\begin{array}{l}3,2 \pm \\
0,54 \\
\end{array}$ & & $\begin{array}{l}1,1 \pm \\
0,03\end{array}$ \\
\hline \multicolumn{6}{|c|}{ Spleen } \\
\hline Large lymphocytes & $\begin{array}{l}5,81 \pm 0,1 \\
3\end{array}$ & $\begin{array}{l}2,45 \pm \\
0,08^{*}\end{array}$ & $\begin{array}{l}1,0 \pm \\
0,54\end{array}$ & & $\begin{array}{l}6,2 \pm \\
0,43^{*}\end{array}$ \\
\hline $\begin{array}{l}\text { Middle } \\
\text { lymphocytes }\end{array}$ & $\begin{array}{l}4,87 \pm 0,1 \\
4\end{array}$ & $\begin{array}{l}9,48 \pm 0,9 \\
5\end{array}$ & $\begin{array}{l}5,3 \pm \\
2,07 \\
\end{array}$ & & $\begin{array}{l}10,1 \pm \\
1,02 \\
\end{array}$ \\
\hline Small lymphocytes & $\begin{array}{l}88,45 \pm \\
2,05\end{array}$ & $\begin{array}{l}65,14 \pm \\
1,02 *\end{array}$ & $\begin{array}{l}89,0 \pm \\
1,77\end{array}$ & & $\begin{array}{l}79,2 \pm \\
1,65\end{array}$ \\
\hline CD8+ & $\begin{array}{l}38,51 \pm \\
1,02\end{array}$ & $\begin{array}{l}54,25 \pm \\
0,47 \\
\end{array}$ & $\begin{array}{l}45,4 \pm \\
0,09 \\
\end{array}$ & & $\begin{array}{l}49,9 \pm \\
0,09\end{array}$ \\
\hline CD25+ & $\begin{array}{l}7,54 \pm 0,0 \\
1\end{array}$ & $\begin{array}{l}3,28 \pm 0,0 \\
01^{*}\end{array}$ & $\begin{array}{l}4,01 \pm \\
0,001\end{array}$ & & $\begin{array}{l}6,46 \pm \\
0,01 *\end{array}$ \\
\hline $\begin{array}{l}\text { Monocytes/macrop } \\
\text { hages }\end{array}$ & $\begin{array}{l}2,45 \pm 0,0 \\
5\end{array}$ & $\begin{array}{l}6,48 \pm 0,0 \\
8 *\end{array}$ & $\begin{array}{l}3,2 \pm \\
0,81 \\
\end{array}$ & & $\begin{array}{l}5,2 \pm \\
0,96^{*}\end{array}$ \\
\hline \multicolumn{6}{|c|}{ Paraortal lymph node } \\
\hline Large lymphocytes & $\begin{array}{l}8,45 \pm 1,2 \\
4\end{array}$ & $\begin{array}{l}6,74 \pm 2,1 \\
4\end{array}$ & $\begin{array}{l}9,1 \pm \\
0,73\end{array}$ & & $\begin{array}{l}5,6 \pm \\
0,71 \\
\end{array}$ \\
\hline $\begin{array}{l}\text { Middle } \\
\text { lymphocytes }\end{array}$ & $\begin{array}{l}18,36 \pm \\
1,05\end{array}$ & $\begin{array}{l}8,64 \pm \\
0,98^{*} \\
\end{array}$ & $\begin{array}{l}11,2 \pm \\
1,93 \\
\end{array}$ & & $\begin{array}{l}9,9 \pm \\
1,02 \\
\end{array}$ \\
\hline Small lymphocytes & $\begin{array}{l}32,14 \pm \\
1,52\end{array}$ & $\begin{array}{l}69,87 \pm \\
0,18^{*}\end{array}$ & $\begin{array}{l}46,0 \pm \\
2,57\end{array}$ & & $\begin{array}{l}63,1 \pm \\
1,93\end{array}$ \\
\hline CD8+ & $\begin{array}{l}39,18 \pm \\
0,87\end{array}$ & $\begin{array}{l}43,87 \pm \\
5,25\end{array}$ & $\begin{array}{l}45,2 \pm \\
0,38 \\
\end{array}$ & & $\begin{array}{l}37,6 \pm \\
0,74^{*}\end{array}$ \\
\hline CD25+ & $\begin{array}{l}2,57 \pm 0,0 \\
1\end{array}$ & $\begin{array}{l}3,12 \pm 0,0 \\
5\end{array}$ & $\begin{array}{l}4,01 \pm \\
0,11 \\
\end{array}$ & & $\begin{array}{l}2,83 \pm \\
0,03 *\end{array}$ \\
\hline $\begin{array}{l}\text { Monocytes/macrop } \\
\text { hages }\end{array}$ & $\begin{array}{l}6,14 \pm 1,2 \\
4\end{array}$ & $\begin{array}{l}8,36 \pm 2,7 \\
8\end{array}$ & $\begin{array}{l}5,4 \pm \\
0,08 \\
\end{array}$ & & $\begin{array}{l}9,1 \pm \\
0,03 *\end{array}$ \\
\hline \multicolumn{6}{|c|}{ Lymph node inguinal } \\
\hline Large lymphocytes & $\begin{array}{l}8,69 \pm 1,3 \\
2\end{array}$ & $\begin{array}{l}7,54 \pm 2,1 \\
2\end{array}$ & $\begin{array}{l}9,6 \pm \\
0,74 \\
\end{array}$ & & $\begin{array}{l}4,0 \pm \\
0,94^{*}\end{array}$ \\
\hline
\end{tabular}

\begin{tabular}{|l|l|l|l|l|}
\hline Middle & $20,87 \pm$ & $10,14 \pm$ & $18,7 \pm$ & $12,5 \pm$ \\
lymphocytes & 1,24 & $1,47^{*}$ & 1,05 & 1,12 \\
\hline \multirow{2}{*}{ Small lymphocytes } & $58,78 \pm$ & $54,21 \pm$ & $36,8 \pm$ & $56,71 \pm$ \\
& 3,01 & 2,14 & 2,95 & $1,03^{*}$ \\
\hline \multirow{2}{*}{ CD8+ } & $39,18 \pm$ & $45,11 \pm$ & $42,8 \pm$ & $34,8 \pm$ \\
& 2,01 & 3,58 & 0,56 & $0,08^{*}$ \\
\hline \multirow{2}{*}{ CD25+ } & $4,16 \pm 0,0$ & $3,87 \pm 1,0$ & $5,61 \pm$ & $4,21 \pm$ \\
& 3 & 2 & 0,06 & 0,03 \\
\hline Monocytes/macrop & $15,25 \pm$ & $22,15 \pm$ & $12,3 \pm$ & $7,5 \pm$ \\
hages & 1,21 & 3,45 & 0,78 & 1,01 \\
\hline \multicolumn{5}{|l|}{ Iliac lymph node } \\
\hline \multirow{2}{*}{ Large lymphocytes } & $2,24 \pm 0,1$ & $4,12 \pm 2,2$ & $1,3 \pm$ & $3,2 \pm$ \\
& 4 & 5 & 0,05 & $0,09^{*}$ \\
\hline Middle & $9,51 \pm 0,1$ & $4,25 \pm 0,0$ & $2,9 \pm$ & $9,2 \pm$ \\
lymphocytes & 4 & $2 *$ & 0,57 & $0,31^{*}$ \\
\hline \multirow{2}{*}{ Small lymphocytes } & $65,13 \pm$ & $59,25 \pm$ & $51,9 \pm$ & $68,1 \pm$ \\
& 3,24 & 1,12 & 2,07 & 1,12 \\
\hline \multirow{2}{*}{ CD8+ } & $29,15 \pm$ & $32,12 \pm$ & $39,7 \pm$ & $41,5 \pm$ \\
& 0,14 & 1,25 & 0,38 & $0,18^{*}$ \\
\hline \multirow{2}{*}{ CD25+ } & $3,12 \pm 0,0$ & $1,25 \pm 0,0$ & $5,16 \pm$ & $5,73 \pm$ \\
& 4 & 2 & 0,08 & 0,06 \\
\hline Monocytes/macrop & $10,41 \pm 1$, & $6,15 \pm 2,8$ & $13,0 \pm$ & $3,1 \pm$ \\
hages & 12 & 7 & 0,95 & $0,07^{*}$ \\
\hline
\end{tabular}

Note: Int. - intact, Inf. - inflammation, * - significant differences from $10.00 \mathrm{~h}$ of the corresponding group $(\mathrm{p}<0,05$; Mann-Whitney test)

\section{Conclusion}

With the development of inflammation in the uterine mucosa in rats, desynchronosis in the immune system is observed. This allows us to talk about the need to take into account circadian rhythms in the diagnosis and treatment of inflammatory diseases.

\section{References}

[1] E.V. Starkova, T.I. Dergacheva, V.V. Astashov. A method for modeling inflammatory diseases of the female genital organs. Patent for invention RUS 2142163 07/17/1996

[2] V.A. Trufakin, A.V. Shurlygina, S.V. Michurina The lymphoid system is a circadian temporary organization and desynchronosis. Bulletin of the Siberian Branch of the Russian Academy of Medical Sciences. 2012, 32 (1), pp 5-12

[3] K Suzuki, Y Hayano, A Nakai, F Furuta, M Noda. Adrenergic control of the adaptive immune response by diurnal lymphocyte recirculation through lymph nodes. J. Exp. Med, 2016. 213 (12), pp 2567-2574. 